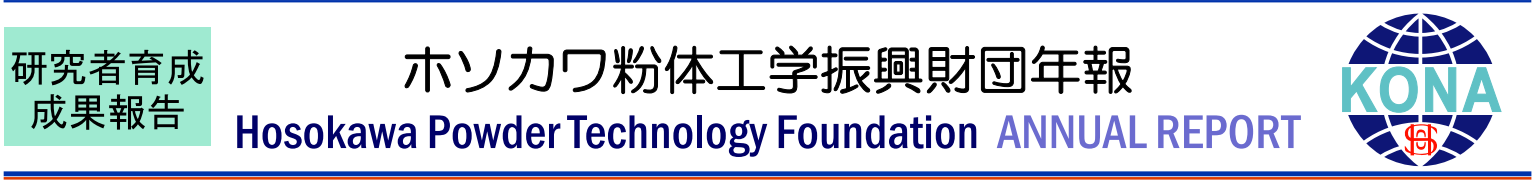

\title{
15504
}

\section{析出速度差を利用した複合粒子作製プロセスの開発 \\ Development of a Particle Composite Process using Difference in Crystallization Rate}

援助対象者 Scholarship Student: 出未 祐人 Yuto DEKI

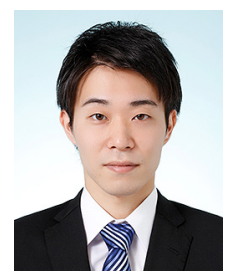

出未 祐人

同志社大学大学院理工学研究科 博士課程後期 2 年

Graduate school of Science and Engineering, Doshisha University, PhD Student (D2)

E-mail: eup1701@mail4.doshisha.ac.jp

\begin{abstract}
研究指導者 Academic Leader：白川 善幸 Yoshiyuki SHIRAKAWA
教授, Professor

E-mail: yshiraka@mail.doshisha.ac.jp
\end{abstract}

\section{成 果 の 概 要}

\section{1. 緒言}

セラミックス, 医薬品, 塗料といった私たち の非常に身近な製品に粉体粒子から作られる材 料が利用されている。 そのため, 多くの素材関 連産業は新規機能性材料の創製を目的に, 粉体 粒子に関する様々な研究を盛んに行っている. 特に，異種物質を接合し，界面構造を制御する ことで新機能を発現させる複合化技術は, 新規 機能性材料の創製手法として注目されている.

粒子の作製には様々な方法があるが，本研究 では二液間の相互溶解による過飽和度の変化を 結晶化の駆動力とし界面上で結晶を析出, 成長 させる手法である液 - 液界面晶析法による粒子 生成を試みた。これまでの研究により, 接触さ せる有機溶媒種，接触時間などのパラメー夕に よる形態制御や多成分溶液からの複合粒子作製 が可能であることが示されており，新規複合化 プロセスとして期待できる。しかし，液 - 液界 面晶析法に扔いて複合形態を決定する重要な因
子である析出速度に有機溶媒の種類および水溶 液中の溶質量が与える影響については未だ十分 に理解されていない.

そこで本研究では, 液 - 液界面晶析法による 複合粒子作製において, 原料の濃度比掞よび有 機溶媒種が複合形態に与える影響を検討した。 また，有機溶媒の拡散速度およびそれぞれの溶 質の析出量を測定することで析出速度に差が生 じる理由についても考察した。

\section{2. 実験方法および解析方法}

モデル物質として塩化ナトリウムと 3 種類の 試薬（グリシン，アラニン， システイン）を選 択した，塩化ナトリウム水溶液にそれぞれの試 薬を添加し, 異なる濃度比で混合溶液を調製し た。その後, 溶液を有機溶媒中に吐出した。溶 液が有機溶媒中に拡散し, 結晶が析出する様子 をカメラ撮影した。得られた粒子の形態は走査 型電子顕微鏡（SEM）を用いて評価した。

次に, 溶媒の拡散速度を算出した，有機溶媒 中に水の液滴の作製し、すべてが溶解するまで 
をカメラで撮影した。拡散速度は液滴の表面積 と体積の時間変化から求めた，また，平面界面 を用いた液 - 液界面晶析法により, それぞれの 溶質の析出量を測定した。このとき，4種の有 機溶媒（1-ブタノール，2-ブタノール，2-ブタ ノン, 2-メチル-1-プロパノール）を用いた.

\section{3. 実験結果および考察}

\section{1 析出挙動および粒子形態の観察}

塩化ナトリウムとグリシンを様々な割合で加 えた混合溶液を使用したときの SEM 画像を Fig. 1 に示す.グリシンの場合, いずれの割合 においても塩化ナトリウムよりもグリシンが先 に析出した。グリシンの結晶はシリンジの先端 付近から析出し, 柱状に成長した。 その後, 液 滴の下部より塩化ナトリウムの結晶が析出し, 先に析出していたグリシンの結晶に付着するよ うな形となった。

塩化ナトリウムとアラニンを様々な割合で加 えた混合溶液を使用したときの SEM 画像を Fig. 2 に示す.グリシンの時と同様に，アラニ ンがシリンジの先端付近で析出し, 液滴の下部 から析出した塩化ナトリウムがアラニンの結晶 に付着するような形となった。塩化ナトリウム

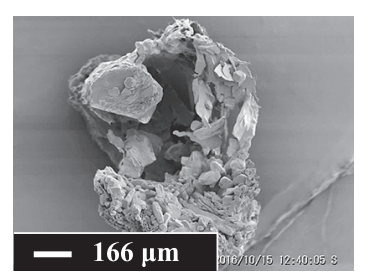

(a) $\mathrm{NaCl}<$ Glycine

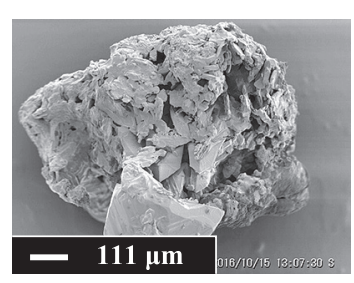

(b) $\mathrm{NaCl}>$ Glycine
Fig. 1 SEM photographs of NaCl-Glycine composite particle.

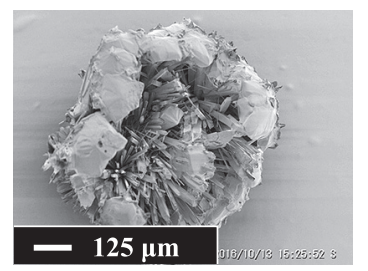

(a) $\mathrm{NaCl}<$ Alanine

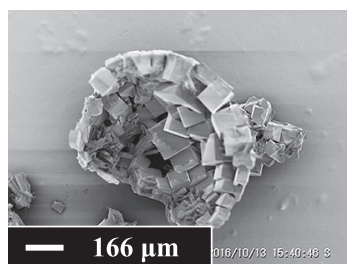

(b) $\mathrm{NaCl}>$ Alanine
Fig. 2 SEM photographs of NaCl-Alanine composite particle.
の割合が多い場合（Fig. 2 (b)），塩化ナトリウ ムの結晶が先に液滴の全体から析出し, その後 アラニンの結晶が析出した，塩化ナトリウムの 結晶が多量に液滴の全体から析出したことで, 液滴の形を保ったまま徐々に溶液が拡散して 小さくなり, 球状の凝集体が得られた。この場 合塩化ナトリウムが外側を覆った複合粒子と なった。

塩化ナトリウムとシステインを様々な割合で 加えた混合溶液を使用したときの SEM 画像を Fig. 3 に示寸. システインの割合が多い場合 (Fig. 3 (a)），塩化ナトリウムが外側に，塩化ナトリ ウムの割合が多い場合 (Fig. 3 (b)), 析出挙動の 観察より, システインの割合が多い場合, 先に L- システインの結晶が全体から析出し, 後から 塩化ナトリウムの結晶が有機溶媒側へと突き出 したような形で析出していることがわかった。 また，塩化ナトリウムの割合が多い場合，塩化 ナトリウムの結晶が先に析出し, 後から全体的 にシステインの結晶が析出していることが確認 できた。このように, 結晶が析出する順番が作 製した粒子の複合形態に大きく影響しているこ とが分かった，塩化ナトリウムの結晶の形に変 化が見られたのは，システインが媒晶剤として 働いたからであると考えられる，塩化ナトリウ ムの結晶は通常六面体であるが，システインが 媒晶剤として働くことで結晶形状が八面体にな ることが知られている、複合粒子の構造の制御 には，使用する二つの物質が及ぼしあう影響に ついても十分に考慮しなければならないことが わかった. 様々な濃度比で観察を行なった結果, 濃度比が析出挙動, 作製した粒子の構造に大き



(a) $\mathrm{NaCl}<$ Cysteine

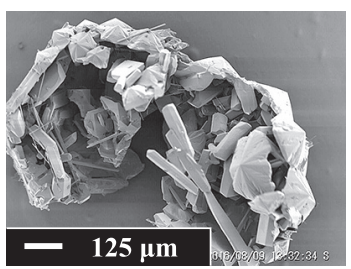

(b) $\mathrm{NaCl}>$ Cysteine
Fig. 3 SEM photographs of $\mathrm{NaCl}$-Cysteine composite particle. 
な影響を与えていることが分かった。

塩化ナトリウムに対して 3 種類の試薬を用い て析出挙動を観察した結果を比較すると, グリ シンではいずれの濃度比においてもグリシンが 先に析出したが, アラニン, システインにおい ては濃度比によって析出する順番が変化したこ とが確認できた。

2 種類の溶質からなる混合溶液から複合粒子

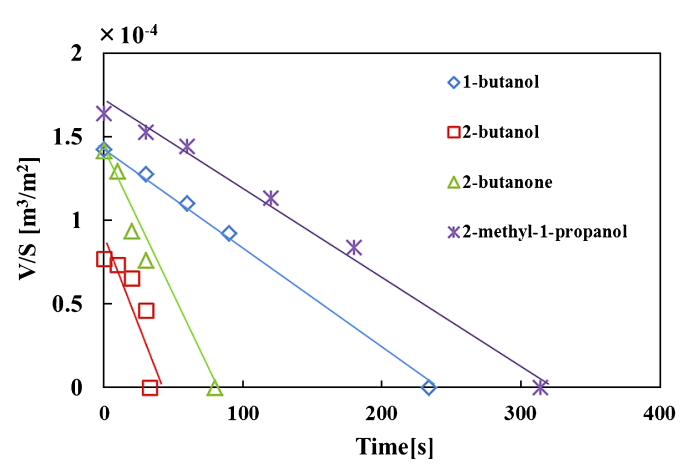

Fig. 4 Volume per unit surface area (V/S) of water droplets in organic solvents as a function of time.

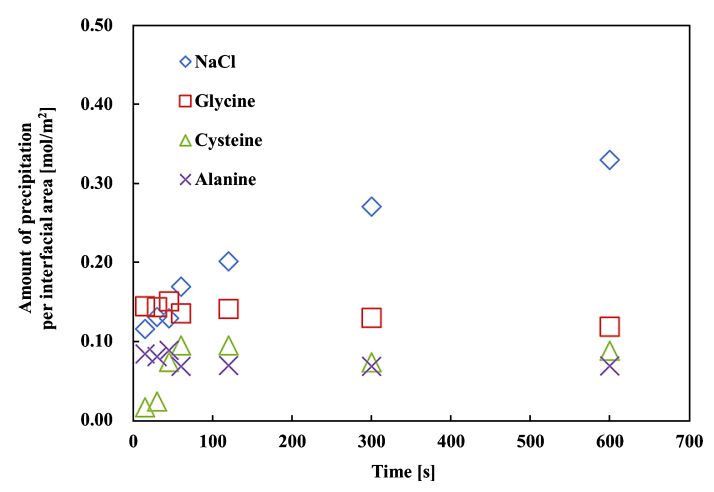

(a) 1-butanol

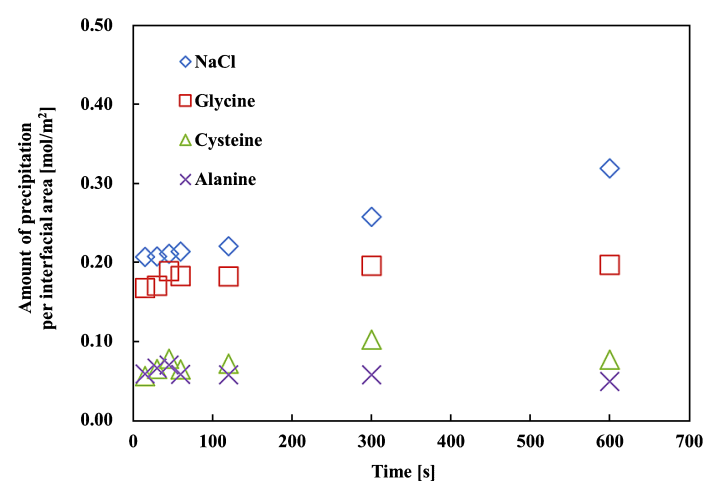

(c) 2-methyl-1-propanol
を作製した場合，2つの溶質の析出速度が等し ければ内部分散型になり，析出速度に差があれ ば，析出速度が速い溶質が先に外側に析出し， 析出速度の遅い溶質が内側に析出するという被 覆型の複合粒子になると考えられる。しかし， 析出挙動の観察では, 先に析出した溶質を後か ら析出した溶質が覆うという場合も見られた。 この結果には, シリンジの先端で不均一核生成 を起こしていることや液滴径が大きく液滴内で 粒子が対流してしまうことが影響していると考 えられる. 本研究では析出挙動の観察のために シリンジで液滴を吐出するという方法を用いた が，実際に複合粒子を作製する場合は有機溶媒 や温度場に微小な液滴を生成する手法が用いら れ, 不均一核生成や粒子の対流の影響は小さい. そのため, 実際のプロセスにおいては適切な濃 度比を設定し析出する順番を操作することがで きれば，複合形態の制御が可能であると考えら れる。



(b) 2-butanol

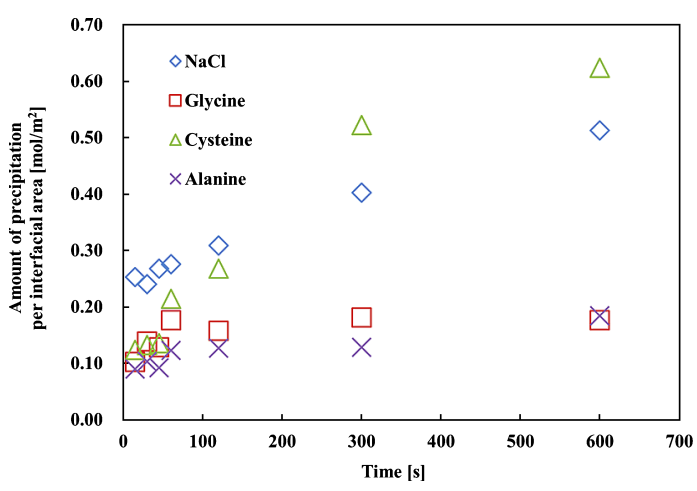

(d) 2-butanone

Fig. 5 Amount of precipitation as a function of time for each organic solvent. 
3.2 水/有機溶媒系における水の拡散速度 拡散速度は単位時間・単位面積あたりの移動 量の時間微分で定義される。そのため, 液滴の 体積を $\mathrm{V}$ ，表面積を $\mathrm{S}$ とし，縦軸に V/S $\left[\mathrm{m}^{3} / \mathrm{m}^{2}\right]$ を横軸に時間をとり，その傾きから拡散速度を 算出した.グラフを Fig. 4 に示す. 2-ブタノール, 2-ブタノンへの純水の拡散速度が1-ブタノー ル，2-メチル-1-プロパノールを用いた場合に比 べて非常に速いことがわかった。液 - 液界面晶 析法において, 溶媒の拡散速度は過飽和状態を 形成する速度に等しい. 用いる有機溶媒との親 和性により, 溶質個々の析出速度も変化すると 考えられるため, 有機溶媒の変更という簡単な プロセスで析出速度の制御が可能であると考え られる。

\section{3 各有機溶媒における析出量}

4 種類の有機溶媒を用いて，それぞれの溶質 の析出量を測定した結果を Fig. 5 に示す. 塩化 ナトリウムは時間を長くすると析出量も増加し たが,グリシン, アラニン, システインはほぼ 一定の值となった。これらのことから, 溶質ご とに析出量が大きく異なることが確認できた. また, 有機溶媒ごとに水との相互溶解度が異な るため, 有機溶媒の種類によっても析出量が変

\section{外部 発表成果}

\section{論文発表}

1. Y. Deki, K. Kadota, Y. Tozuka, A. Shimosaka, Y. Shirakawa, "Mutual diffusion diagram of liquidliquid interfaces for morphological control of $\mathrm{NaCl}$ crystals" J. Mol. Liq. 223 (2016) 462-468.

\section{口頭・ポスター発表}

1. 出未祐人, 下坂 厚子, 吉田幹生, 白川善幸, “数值解析による液液二相界面拡散現象の定
化することがわかった，析出量の時間変化から $15 \mathrm{~s}$ から $60 \mathrm{~s}$ という短い時間において, 1-ブ夕 ノールを用いた場合はグリシンの析出量が塩化 ナトリウムの析出量を上回っていた。一方，2ブタノールを用いた場合はいずれの時間におい ても塩化ナトリウムの析出量の方が大きくなっ た. 析出挙動の観察結果では, いずれの濃度条 件においてもグリシンが先に析出したが, 有機 溶媒を2-ブタノールに変えることで析出の順番 が変わり, 塩化ナトリウムの結晶を先に析出さ せることができるのではないかと考えられる。

\section{4. まとめ}

液一液界面晶析法を用いた複合粒子の作製に おいて, 原料の濃度比が作製した粒子の形態に 与える影響について検討し, 複合構造を制御す ることを試みた。 原料の濃度比によって析出挙 動や作製した粒子の形態に大きな影響を与えて いることが分かった，また，有機溶媒の種類に よっても析出挙動, 粒子の形態が変化すること が分かった，そのため, 液一液界面晶析法を用 いた複合粒子の作製において, 濃度比と適切な 有機溶媒の選択によって制御が可能であること が示唆された。

量化と結晶形態の予測” 粉体工学会 第 51 回技術討論会, 東京, 2016 年 6 月.

2. 出未祐人, 下坂厚子, 吉田幹生, 白川善幸, “経験的知見から脱出! 結晶は頭で作 れ!!”化学工学会第 4 回シーズフォーラ 么, 京都, 2016 年 10 月.

3. 出未祐人, 下坂厚子, 吉田幹生, 白川善幸, “拡散方程式を用いた液液二相間に掞ける界 面近傍の濃度計算と析出結晶の形態制御” 粉体工学会秋期研究発表会, 東京, 2016 年 11 月. 